\title{
Embryonic life of the loliginid squid Loligo vulgaris: comparison between statoliths of Atlantic and Mediterranean populations
}

\author{
R. Villanueva ${ }^{1, *}$, A. Arkhipkin ${ }^{2}$, P. Jereb ${ }^{3,8}$, E. Lefkaditou ${ }^{4}$, M. R. Lipinski ${ }^{5}$, \\ C. Perales-Raya ${ }^{6}$, J. Riba ${ }^{1}$, F. Rocha ${ }^{7}$ \\ ${ }^{1}$ Institut de Ciències del Mar (CSIC), Passeig Marítim 37-49, 08003 Barcelona, Spain \\ ${ }^{2}$ Falkland Islands Government Fisheries Department, PO Box 598, Stanley, Falkland Islands \\ ${ }^{3}$ Istituto di Ricerche sulle Risorse Marine e l'Ambiente, Consiglio Nazionale delle Ricerche (IRMA-CNR), \\ Via Luigi Vaccara 61, 91026 Mazara del Vallo, Italy \\ ${ }^{4}$ Institute of Marine Biological Resources (IMBR), Aghios Kosmas, 16604 Helliniko, Greece \\ ${ }^{5}$ Marine and Coastal Management, DEAT, Private Bag X2, Roggebaai 8012, South Africa \\ ${ }^{6}$ Centro Oceanográfico de Canarias, Instituto Español de Oceanografía, Carretera de San Andrés s/n, \\ 38120 Santa Cruz de Tenerife, Spain \\ ${ }^{7}$ Instituto de Investigaciones Marinas (CSIC), Eduardo Cabello 6, 36208 Vigo, Spain
}

${ }^{8}$ Present address: Istituto Centrale per la Ricerca Scientifica e Tecnologica Applicata al Mare (ICRAM), Via di Casalotti 300, 00166 Roma, Italy

\begin{abstract}
Egg masses of the loliginid squid Loligo vulgaris Lamarck, 1798 are attached to hard substratum or branched sessile organisms on the sea bottom. Embryonic development lasts from a few weeks to a few months, depending on the environmental water temperature. Because embryonic statolith growth of $L$. vulgaris is very sensitive to temperature under laboratory conditions, we analyzed the possibilities of determining past events in the squid's early life from analysis of the embryonic area of statoliths of wild squid populations. The relationship between egg-incubation temperature and daily growth of embryonic statoliths under laboratory conditions was determined by tetracycline markings at 10 incubation temperatures ranging from 12 to $24.7^{\circ} \mathrm{C}$. In addition, the mean width of embryonic increments in statolith collections of wild L. vulgaris from the Eastern Atlantic (Saharan Bank and NW Iberian Peninsula) and the Mediterranean Sea (Central and Eastern) was calculated. The temperature inferred from the embryonic increment widths of the statoliths of wild squid indicates that embryonic development of $L$. vulgaris in the regions sampled is likely to occur at temperatures ranging from 12 to $17^{\circ} \mathrm{C}$. Mediterranean squid have wider embryonic increments than Atlantic squid, reflecting the slightly higher water temperatures in the Mediterranean Sea during the development of the egg masses. Eggs of $L$. vulgaris spawned off the NW Iberian Peninsula were estimated, on average, to remain at sea for $47 \mathrm{~d}, 1$ wk longer than Mediterranean eggs (nearly 1 mo longer when comparing minimum and maximum ranges). A longer incubation time for egg masses attached to the sea bottom increases mortality risks. Conversely, slow development at a lower temperature can improve yolk conversion, producing larger hatchlings, and increased hatching competence is expected from such squid. Therefore, a compromise between longer-versus-shorter incubation time and related characteristics does exist.
\end{abstract}

KEY WORDS: Cephalopods · Spawning sites $\cdot$ Embryonic development $\cdot$ Eggs $\cdot$ Larvae $\cdot$ Growth $\cdot$ Statoliths Resale or republication not permitted without written consent of the publisher

\section{INTRODUCTION}

Loliginid squids are fast-growing coastal cephalopods. Their initial life cycle, i.e. embryonic develop- ment, lasts from a few weeks to a few months. The post-hatching life of most species is $\leq 1 \mathrm{yr}$. Embryonic development depends on the environmental water temperature which, for Loligo vulgaris Lamarck, 1798, 
ranges from $>3 \mathrm{mo}$ at $10^{\circ} \mathrm{C}$ to $\sim 1 \mathrm{mo}$ at $20^{\circ} \mathrm{C}$ (von Boletzky 1974). Studies on the age and growth of $L$. vulgaris from statolith analysis have estimated the duration of their post-hatching life to be about 1 yr, i.e. 240 to 396 d (Natsukari \& Komine 1992, Arkhipkin 1995, Bettencourt et al. 1996, Raya et al. 1999, Rocha \& Guerra 1999). Statolith analysis has proved to be the best tool for estimating loliginid age and growth of wild populations, with nearly all studies focusing on analysis of the post-hatching area of the statolith (see the reviews Jackson 1994 and Jackson \& O'Dor 2001). Less attention has been paid to embryonic statolith analysis. In statoliths of loliginid squids, the nucleus area is outlined by the first increment. The natal ring, which is formed at hatching, is the first prominent growth increment outside the nucleus. A series of growth increments are visible between the nucleus and the natal ring. These growth increments have been reported for the loliginid squids Uroteuthis (Photololigo) edulis (Hoyle, 1885) (Natsukari et al. 1988), L. subulata Lamarck, 1798 (Lipinski 1986, Morris 1991, 1993), Sepioteuthis lessoniana Lesson, 1830 (Jackson 1990, Ikeda et al. 1999), and L. forbesi Steenstrup, 1856 (Collins et al. 1995, Martins 1997, Rocha \& Guerra 1999). For $L$. vulgaris, these increments have been well illustrated in photographs of published studies (see Fig. 1 of Natsukari \& Komine 1992, Fig. 1 of Arkhipkin 1995, Fig. 1 of Martins 1997, Fig. 2 of Rocha \& Guerra 1999 and Fig. 3 of Villanueva 2000b). Egg masses of $L$. vulgaris are laid on the underside of rocky overhangs or on branched sessile organisms (von Boletzky 1998) and fishing lines (Villanueva 2000b; see also 'Materials and methods' of present study) and hang down in the water. These egg masses comprise dozens to hundreds of finger-like egg capsules, 60 to $160 \mathrm{~mm}$ in length, each capsule containing an average of 90 eggs (Mangold-Wirz 1963). L. vulgaris is an interesting model for study because its spawning period extends throughout the year, both in the Atlantic (Coelho et al. 1994, Guerra \& Rocha 1994, Arkhipkin 1995) and the Mediterranean Seas, and egg masses can be collected year-round (Mangold-Wirz 1963, Villanueva 2000a). Temperature and food are probably the most important factors that affect cephalopod growth. Squid statoliths reflect the influence of temperature during prehatching (Villanueva 2000b) and post-hatching life (Durholtz \& Lipinski 2000, Villanueva 2000a) as well as food ration (Jackson \& Moltschaniwskyj 2001). During embryonic development, yolk reserves provide a constant nutrient flow to the embryo, and it can be assumed that embryonic statolith growth is not limited by external nutrients as occurs in post-hatching squids. Therefore, the environmental water temperature is probably the most important influence on embryonic statolith growth. Other factors such as egg position, biofouling and (probably) salinity changes, are sources of variability in embryonic development observed in the field for the loliginid squid Sepioteuthis australis, and should also be taken into consideration (Gowland et al. 2002, Steer et al. 2002).

In Loligo vulgaris, daily deposition of statolith growth increments has been validated under different conditions and stages of development. In the field, as well as in the laboratory, daily increment deposition in statoliths of adult L. vulgaris reynaudii d'Orbigny, 1845 has been determined by tetracycline marking and recapture (Lipinski et al. 1998, Durholtz et al. 2002). In the laboratory, statolith increments of embryos and paralarvae of $L$. vulgaris have been validated under different temperature conditions by multiple tetracycline marking, and have shown that cool temperatures can affect statolith increment deposition (Villanueva $2000 a, b)$. These laboratory results revealed a daily increment deposition rate over 2 mo of paralarval rearing at 11 and $19.5^{\circ} \mathrm{C}$. However, at the lower temperature, only $21 \%$ of the statoliths were readable. For embryonic statoliths the following observations were made: (1) increases in statolith length ( $\left.\% \mathrm{~d}^{-1}\right)$ between tetracycline marks were up to 5 times higher for embryos incubated at $21^{\circ} \mathrm{C}$ than for those incubated at $12^{\circ} \mathrm{C}_{i}(2)$ increment deposition was daily at $15.5^{\circ} \mathrm{C}$, but less-than-daily at $12^{\circ} \mathrm{C}_{i}(3)$ when embryos incubated at cool temperatures were transferred to warm conditions, statolith growth rates increased, indicating the plasticity of statolith growth.

These laboratory results demonstrated that embryonic statoliths are very sensitive to temperature and suggested the possible usefulness of the embryonic area of the statolith in determining past events of the squid's early life cycle in wild populations. With this aim, the present study had 2 objectives. The first was to determine the relationship between egg incubation temperature and embryonic statolith growth in Loligo vulgaris. Accordingly, a series of 10 incubation temperatures (ranging from 12 to $24.7^{\circ} \mathrm{C}$ ) were analyzed for groups of independent egg capsules. The second objective was to measure the width of the embryonic increments in statoliths from wild $L$. vulgaris individuals (juveniles to adults) from different, well-differentiated geographic regions, i.e. the East Atlantic and the Mediterranean Sea. Statolith collections from previously published studies on L. vulgaris age and growth (Arkhipkin 1995, Raya et al. 1999, Rocha \& Guerra 1999) were analyzed, as well as newly collected material. From these aged statoliths it was possible to estimate by back-calculation the respective hatching dates and the sea temperature ranges recorded for each geographic region at hatching. Thus, a comparison was possible between the recorded sea temperatures and the sea temperatures inferred from the rela- 
tionship obtained in the laboratory between embryonic statolith growth and incubation temperature, opening the possibility of using these embryonic statolith characters to determine past events in the early life of squid.

\section{MATERIALS AND METHODS}

Embryonic statoliths of Loligo vulgaris incubated under laboratory conditions. The experimental procedure was as follows:

Collection of material: Two recently spawned egg masses of Loligo vulgaris were collected from fishing lines deployed $24 \mathrm{~h}$ before egg collection at depths of 15 to $30 \mathrm{~m}$ off Barcelona, Spain (NW Mediterranean). Thus, the time of collection period corresponded to the maximum age of the eggs. Egg capsules were transported to the laboratory on the same day and maintained in the open-circuit seawater system of the Institut de Ciències del Mar, Barcelona. They were incubated suspended near the surface in a $200 \mathrm{l}$ tank by a nylon fishing thread passed through the mucilaginous mass at the base of the capsules. A high flow rate of $200 \mathrm{l} \mathrm{h}^{-1}$ ensured that the egg capsules remained in constant gentle motion with good ventilation. Egg Mass A was collected on 4 May 2000, and the whole egg mass was incubated for $15 \mathrm{~d}$ at a temperature of $15.6^{\circ} \mathrm{C}$ (range 15.3 to $15.8^{\circ} \mathrm{C}$ ). Egg Mass B was collected on 24 April 2001, and the whole egg mass was incubated for $12 \mathrm{~d}$ at a temperature of $20.2^{\circ} \mathrm{C}$ (range 19.9 to $20.5^{\circ} \mathrm{C}$ ).

Tetracycline staining and temperature regime between staining marks. The general procedures followed those of Villanueva (2000b). Egg masses A and B were both stained on 2 occasions $\left(M_{1}\right.$ and $\left.M_{2}\right)$. The first staining $\left(\mathrm{M}_{1}\right)$ occurred $15 \mathrm{~d}$ (Egg Mass A) or $12 \mathrm{~d}$ (Egg Mass B) after collection by immersing the egg capsules for $3 \mathrm{~h}$ in a solution of $750 \mathrm{mg} \mathrm{l}^{-1}$ tetracycline in seawater in 51 tanks with gentle aeration. Staining was always made between 10:00 and 13:00 h, after which the egg capsules were returned to the incubation tank. After $M_{1}$ staining, the egg capsules of the whole egg masses were divided into 4 groups $(1,2,3,4)$ for Egg Mass A and 3 groups $(5,6,7)$ for Egg Mass B, with each group comprising 10 to 15 egg capsules. Group 1 was incubated at a mean temperature of $13.3^{\circ} \mathrm{C}(13.2$ to $\left.13.4^{\circ} \mathrm{C}\right)$, Group 2 at $17.5^{\circ} \mathrm{C}\left(17.4\right.$ to $\left.17.6^{\circ} \mathrm{C}\right)$, Group 3 at $19.7^{\circ} \mathrm{C}$ (19.3 to $20.4^{\circ} \mathrm{C}$ ), and Group 4 at $24.7^{\circ} \mathrm{C}$ (24.1 to $25.6^{\circ} \mathrm{C}$ ). Group 5 was incubated at a mean temperature of $16.7^{\circ} \mathrm{C}\left(16.3\right.$ to $\left.17.3^{\circ} \mathrm{C}\right)$, Group 6 at $22.4^{\circ} \mathrm{C}(22.2$ to $\left.22.5^{\circ} \mathrm{C}\right)$ and Group 7 at $23.5^{\circ} \mathrm{C}\left(22.9\right.$ to $\left.23.9^{\circ} \mathrm{C}\right)$. The second staining $\left(\mathrm{M}_{2}\right)$ was performed $7 \mathrm{~d}$ later for all temperature groups, except Groups 1 and 3, for which the time between stainings was 14 and 13 d, respectively.
To avoid temperature shock, the egg capsules were gradually acclimatized to the new temperatures at a rate of $1^{\circ} \mathrm{C} \mathrm{h}^{-1}$. Incubations were carried out in separate $40 \mathrm{l}$ tanks, using $250 \mathrm{l}$ and 7001 closed seawater systems provided with automatic temperature control (Villanueva 2000b). Constant, low-intensity illumination was maintained at $1.5 \mu \mathrm{E} \mathrm{m}^{-2} \mathrm{~s}^{-1}$ at $1 \mathrm{~cm}$ below the water surface. $\mathrm{M}_{2}$ staining was undertaken at the individual incubation temperatures. The temperature was then raised and maintained at $19.1^{\circ} \mathrm{C}\left(18.5\right.$ to $\left.19.4^{\circ} \mathrm{C}\right)$ for all groups until hatching. Sets of data on embryonic statolith growth from tetracycline validation studies of Loligo vulgaris (Villanueva 2000b) have been included in the present research. These data correspond to 3 groups of egg capsules treated following the same protocol as above and incubated at mean temperatures of

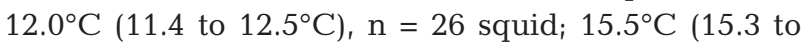
$\left.15.8^{\circ} \mathrm{C}\right), \mathrm{n}=26$ squid; $^{\text {and }} 21.1^{\circ} \mathrm{C}\left(20.4\right.$ to $\left.21.8^{\circ} \mathrm{C}\right), \mathrm{n}=$ 25 squid (Villanueva 2000b).

Collection and preparation of marked statoliths: After $\mathrm{M}_{2}$ staining, hatchling squid of each group were collected daily between 09:00 and 10:00 h. Squid were anaesthetized in $2 \%$ ethanol and the temperature was lowered to $1-4^{\circ} \mathrm{C}$; they were then fixed in $95 \%$ ethanol and counted. For the statolith analysis of each group, we selected squid hatched during the day of maximum hatching intensity in that group. Statoliths were removed under the dissecting microscope at a magnification of $\times 40$ and extracted with the tip of a scalpel. The statoliths were placed posterior-side up on a microscope slide and allowed to dry. They were then covered with a drop of Protexx synthetic mountant. The statoliths were not ground or polished, since tetracycline-stained bands are clearly visible under the fluorescent microscope. The statoliths were observed under a Nikon Diaphot 200 light microscope equipped with a $100 \mathrm{~W}$ Nikon HB-10101AF mercury lamp and neofluor $\times 10, \times 20$, and $\times 40$ lenses. The microscope was connected to a Sony CCD-Iris colour video-camera, which was in turn connected to a video-recorder and a TV monitor. The statolith images were recorded on a video-cassette and analyzed in a personal computer equipped with a video-card using the image-analyzer program NIH Image, Version 1.61. Various measurements were made on the image of each statolith (definitions and terminology of Clarke 1978 and Lipinski et al. 1991). Statolith length (SL) at the level of the fluorescent stained bands $M_{1}$ and $M_{2}$ was recorded at a magnification of $\times 200$ using neofluor lenses; the distance between the fluorescent bands was measured in 3 statolith areas, the dorsal dome, lateral dome and the rostrum. Measurements were made on the statoliths of 25, 26, 25 and 25 squid from Groups 1, 2, 3 and 4, respectively, and from 29, 27 and 29 squid from Groups 5,6 and 7 , respectively. 
Analysis of embryonic statoliths from wild squid populations. Collection, measurements and data analysis were as follows:

Collection of material: Data and statolith collections from previously published studies on Loligo vulgaris age and growth were re-examined as well as unpublished data from new statolith collections. From all collections, only aged statoliths with some ( $\mathrm{n}=4$ to 10 ) embryonic growth increments, clearly visible on the dorsal dome, were selected. This procedure was followed because the growth of the dorsal dome area in the embryonic statolith was highly correlated with the incubation temperature of the embryos under laboratory conditions (see 'Results'). Of the total number of aged statoliths of L. vulgaris ( $\mathrm{n}=582)$, only $238(41 \%)$ showing clear increments in the dorsal dome region of the embryonic statolith were used in the present study. Statoliths used from previous published studies were: 101 squids ranging from 43 to $353 \mathrm{~mm}$ mantle length (ML) from Saharan Bank (Arkhipkin 1995), designated 'Saharan Bank-1'; 30 squids ranging from 65 to 508 mm ML from Saharan Bank (Raya et al. 1999), designated 'Saharan Bank-2'; 43 squids ranging from 92 to $400 \mathrm{~mm}$ ML from Galicia, NW Iberian Peninsula, NE Atlantic (Rocha \& Guerra 1999). Detailed squid collection data are provided in the relative studies cited. Statoliths from unpublished collections (Table 1) were: 43 L. vulgaris (44 to $400 \mathrm{~mm} \mathrm{ML}$ ), collected from February to November 1995 by means of bottom trawling in the Strait of Sicily, Central Mediterranean; 21 L. vulgaris (77 to $366 \mathrm{~mm} \mathrm{ML),} \mathrm{collected} \mathrm{from} \mathrm{September} 1991$ to April 1992 by bottom trawling and beach-seine in the Thracian Sea, Eastern Mediterranean. Table 1 summarizes the age of the squids examined and Fig. 1 indicates the geographical areas for all squids collected.

Statolith analysis, hatching dates and field temperatures: All statoliths were mounted posterior- or anteriorside up, and were ground and polished on both sides. Growth increments were counted from the natal ring according to techniques described by Arkhipkin 1995, Raya et al. 1999 and Rocha \& Guerra 1999. Post-hatching statolith growth increments from all statolith col- lections were assumed to be daily, as their deposition has been validated by the use of tetracycline, both in the wild for subadult and adult Loligo vulgaris reynaudii (Lipinski et al. 1998), and for laboratory cultures of L. vulgaris paralarvae (Villanueva 2000a). In this way, the hatching date of each squid was estimated by back-calculation from the date of capture and increment counts. The years of hatching of each squid collection are indicated in Table 1. For each statolith collection, squid were grouped by month of hatching. Data for squid hatched in the same month but in different years were pooled.

The mean increment width (4 to 10 growth increments) was measured on the dorsal dome area of the embryonic statolith, using image-analysis systems

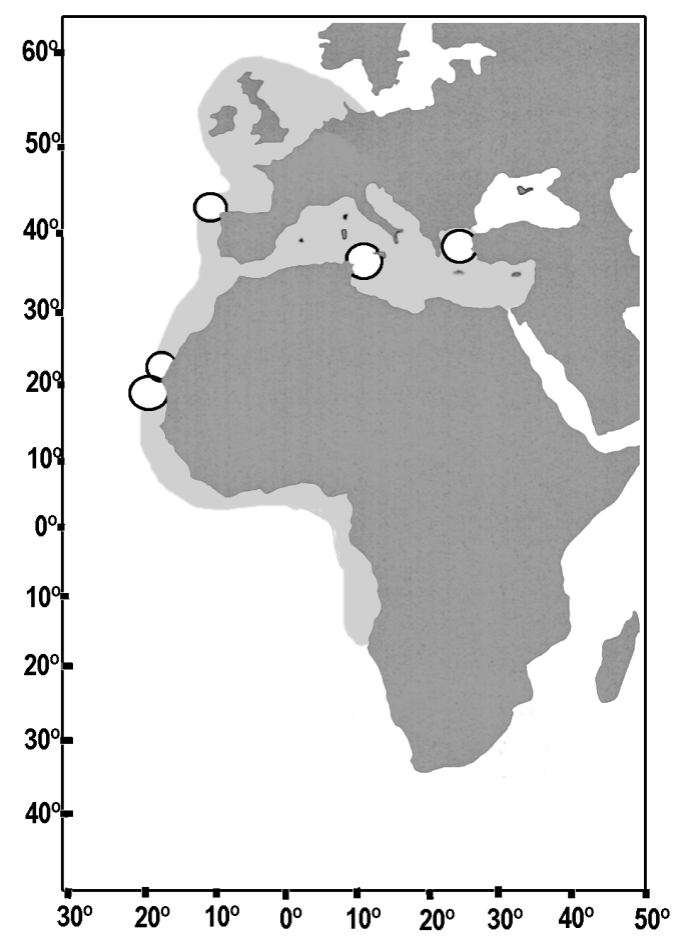

Fig. 1. Loligo vulgaris. Map of Atlantic showing distribution and origins of material used during the present study $(0)$

Table 1. Loligo vulgaris. Wild-collected squid from which embryonic statolith increment widths were obtained. For each geographic area, age range of squid (obtained from statolith growth-increment counts), year of hatching (estimated by backcalculation from date of capture and increment counts), number of squid used, and source of the material are indicated

\begin{tabular}{|c|c|c|c|c|}
\hline Geographic area & $\begin{array}{l}\text { Age range } \\
\text { (d) }\end{array}$ & $\begin{array}{l}\text { Hatching } \\
\text { years }\end{array}$ & $\mathrm{n}$ & Source \\
\hline Saharan Bank-1, NE Atlantic & $135-342$ & $1984-1987$ & 101 & Arkhipkin (1995) \\
\hline Saharan Bank-2, NE Atlantic & $129-249$ & $1992-1993$ & 30 & Raya et al. (1999) \\
\hline NW Iberian Peninsula, NE Atlantic & $167-367$ & $1990-1991$ & 43 & Rocha \& Guerra (1999) \\
\hline Central Mediterranean (Strait of Sicily) & $108-315$ & $1994-1995$ & 43 & Unpubl. data \\
\hline Eastern Mediterranean (Thracian Sea) & $137-357$ & $1991-1992$ & 21 & Unpubl. data \\
\hline
\end{tabular}


$(\times 400)$. The software packages used were VIDS for the statolith collection from the NW Iberian Peninsula (Rocha \& Guerra 1999) and NIH Image (see earlier subsection) for the remaining statolith collections. Embryonic growth increments were assumed to be daily for temperatures exceeding $15^{\circ} \mathrm{C}$ (Villanueva $2000 \mathrm{a}, \mathrm{b})$. Mean monthly temperature profiles from 0 to $200 \mathrm{~m}$ depth from the Strait of Sicily ( 37 to $38^{\circ} \mathrm{N}, 12$ to $\left.14^{\circ} \mathrm{E}\right)$ and the Thracian Sea $\left(40^{\circ} 20^{\prime} \mathrm{N}, 23^{\circ} 38^{\prime} \mathrm{E}\right.$ to $41^{\circ} 10^{\prime} \mathrm{N}, 25^{\circ} 58^{\prime} \mathrm{E}$ ), were obtained from the Mediterranean Oceanic Database (Brasseur et al. 1996) and MEDATLAS (2002). Mean monthly temperature profiles from the Saharan Bank in the upwelling areas of 22.5 to $25.5^{\circ} \mathrm{N}$ and 15.5 to $17.5^{\circ} \mathrm{W}$, and also off Cape Blanco, at $20.5^{\circ} \mathrm{N}, 17.5^{\circ} \mathrm{W}$, were obtained from Conkright et al. (1998); mean monthly temperatures from the NW Iberian Peninsula in front of the Ría de Vigo $\left(42^{\circ} 08.05^{\prime} \mathrm{N}, 08^{\circ} 57.5^{\prime} \mathrm{W}\right)$, were obtained from the Centro Oceanográfico de Vigo, Instituto Español de Oceanografía database for the period 1994 to 2000.

Data treatment: Growth rates were calculated using the instantaneous growth coefficient $(G)$ obtained from the equation $G=\left(\log _{\mathrm{e}} Y_{2}-\log _{\mathrm{e}} Y_{1}\right) \times\left(t_{2}-t_{1}\right)^{-1}$, where $Y_{2}=$ final length, $Y_{1}=$ initial length; $t_{1}=$ age in days at $Y_{1}$, and $t_{2}=$ age in days at $Y_{2}$. The relative growth rate (daily per-
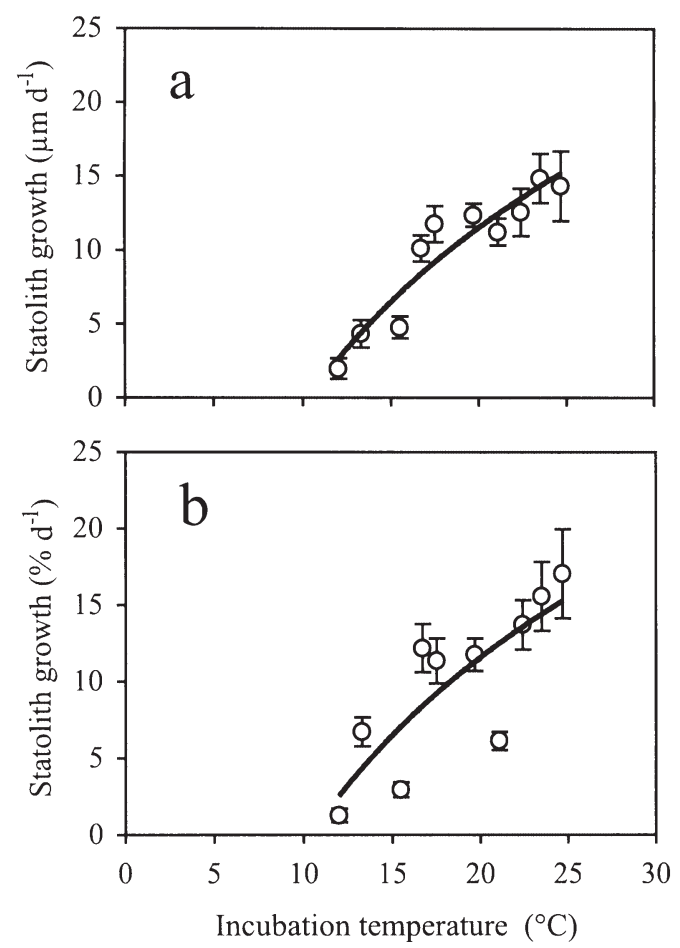

Fig. 2. Loligo vulgaris. Mean $( \pm \mathrm{SD})$ daily statolith growth (a) in length and (b) in percentage, of embryos incubated under laboratory conditions at temperatures ranging from 12.0 to $24.7^{\circ} \mathrm{C}$. Growth was recorded between 2 consecutive tetracycline marks. Logarithmic trend is indicated for each plot centage gain in length) was calculated by multiplying $G$ by 100 . For comparison of the tetracycline-stained statoliths, values were transformed to meet the requirements of normality (Shapiro-Wilk method), after logtransformation of length data $\left(\mu \mathrm{m} \mathrm{d}^{-1}\right)$ and arcsinetransformation of growth rate data $\left(\% \mathrm{~d}^{-1}\right)$. Data were compared by Student's $t$-tests and ANOVA followed by the Tukey-Kramer HSD test, at 0.05 significance level. Tests were done using the JMP statistical package.

\section{RESULTS}

\section{Embryonic statolith growth under laboratory conditions}

Normal hatching success was observed in all groups of Loligo vulgaris embryos except for the group incubated at the higher temperature $\left(24.7^{\circ} \mathrm{C}\right)$, where total mortality was observed in 11 egg capsules $(73 \%$ of the total), and embryos from the remaining 4 egg capsules hatched prematurely, while still posessing large outer yolk sacs. After the first staining, growth occurred in all statoliths between the fluorescent stained bands $M_{1}$ and $\mathrm{M}_{2}$. Incubation temperature clearly influenced the statolith growth, and this variable was strongly and positively correlated with all measurements recorded in the statoliths (Student's- $t, \mathrm{p}<0.00001$ ). A wide range of statolith growth rates was observed, depending on the incubation temperature (Table 2, Figs. 2 \& 3). As a consequence, the growth in total statolith length of the embryos incubated at $23.5^{\circ} \mathrm{C}$ was more than 7 times that of embryos incubated at the lower temperature $\left(\mu \mathrm{m} \mathrm{d}^{-1}\right)$. Moreover, $24.7^{\circ} \mathrm{C}$ squid had statolith growth rates $\left(\% \mathrm{~d}^{-1}\right)$ that were 13 times greater than those of $12.0^{\circ} \mathrm{C}$ squid (Table 2). It should be noted that the growth as percentage per day $\left(\% \mathrm{~d}^{-1}\right)$ for the statoliths incubated at temperatures of $12.0,15.5$ and $21.1^{\circ} \mathrm{C}$ was lower (Fig. 2b), the reason being that these groups of embryos were incubated at a higher temperature $\left(22.3^{\circ} \mathrm{C}\right.$ ) before the first tetracycline staining (Villanueva 2000b), in comparison with the groups from Egg Masses A and B (incubated, respectively, at 15.6 and $20.2^{\circ} \mathrm{C}$ before the first staining). Therefore, statolith length at $\mathrm{M}_{1}$ was longer at this time in the statoliths incubated by Villanueva (2000b). However, this difference was not observed for growth expressed as micrometers $\left(\mu \mathrm{m} \mathrm{d}^{-1}\right)$ for the same statoliths, as embryonic statolith growth was fairly constant (Fig. 2a). As expected, mean growth in all statoliths was greater in the rostrum and least in the lateral dome. The highest correlation between incubation temperature and statolith growth was obtained for the dorsal dome region. In this region, growth rates differed by up to 7 times between the 2 most extreme temperatures used for 
Table 2. Loligo vulgaris. Mean \pm SD (range) of daily growth in length of embryonic statoliths squid incubated in laboratory. Groups (G) 1-4 represent Egg Mass A, G5-7 represent Egg Mass B. Data for 12.0, 15.5 and $21.1^{\circ} \mathrm{C}$ are from Villanueva (2000b). Measurements shown for 3 statolith zones (dorsal dome, lateral dome, rostrum) and for total statolith length. Length was measured between 2 consecutive tetracycline marks; time elapsed between marks was $7 \mathrm{~d}$, except for G1 and 3 (13.3 and $\left.19.7^{\circ} \mathrm{C}\right)$, where time elapsed was 14 and $13 \mathrm{~d}$, respectively. Means with same superscript letter for same measurement were not statistically different ( $p>0.05)$

\begin{tabular}{|lcccccc|}
\hline $\begin{array}{l}\text { Incubation } \\
\text { temp. }\left({ }^{\circ} \mathrm{C}\right)\end{array}$ & $\mathrm{n}$ & $\begin{array}{c}\text { Dorsal dome } \\
\left(\mu \mathrm{m} \mathrm{d}^{-1}\right)\end{array}$ & $\begin{array}{c}\text { Lateral dome } \\
\left(\mu \mathrm{m} \mathrm{d}^{-1}\right)\end{array}$ & $\begin{array}{c}\text { Rostrum } \\
\left(\mu \mathrm{m} \mathrm{d}^{-1}\right)\end{array}$ & $\begin{array}{c}\text { Statolith length } \\
\left(\mu \mathrm{m} \mathrm{d}^{-1}\right)\end{array}$ \\
\hline 12.0 & 26 & $0.9 \pm 0.2^{\mathrm{a}}(0.6-1.3)$ & $0.8 \pm 0.2^{\mathrm{a}}(0.3-1.1)$ & $1.4 \pm 0.3^{\mathrm{a}}(0.8-2.2)$ & $2.0 \pm 0.7^{\mathrm{a}}(0.5-3.5)$ & $1.3 \pm 0.4^{\mathrm{a}}(0.3-2.3)$ \\
13.3 (G1) & 25 & $1.8 \pm 0.5^{\mathrm{b}}(1.2-3.6)$ & $1.4 \pm 0.3^{\mathrm{b}}(0.9-1.9)$ & $2.3 \pm 0.5^{\mathrm{b}}(1.1-3.7)$ & $4.3 \pm 0.9^{\mathrm{b}}(2.2-7.3)$ & $6.7 \pm 0.9^{\mathrm{b}}(4.3-9.1)$ \\
15.5 & 26 & $2.2 \pm 0.4^{\mathrm{c}}(1.3-3.1)$ & $1.5 \pm 0.3^{\mathrm{b}}(0.8-2.1)$ & $3.5 \pm 0.5^{\mathrm{c}}(2.6-4.5)$ & $4.8 \pm 0.8^{\mathrm{b}}(3.3-6.2)$ & $3.0 \pm 0.5^{\mathrm{c}}(2.2-4.1)$ \\
16.7 (G5) & 29 & $3.9 \pm 0.5^{\mathrm{d}}(3.2-5.1)$ & $2.7 \pm 0.4^{\mathrm{c}}(1.8-3.5)$ & $5.4 \pm 0.7^{\mathrm{d}}(5.5-8.7)$ & $10.1 \pm 0.9^{\mathrm{c}}(8.6-11.4)$ & $12.2 \pm 1.6^{\mathrm{d}}(9.3-15.0)$ \\
17.5 (G) & 25 & $5.0 \pm 0.5^{\mathrm{e}}(4.3-6.2)$ & $3.9 \pm 0.6^{\mathrm{d}}(3.0-5.4)$ & $7.1 \pm 1.0^{\mathrm{e}}(5.2-8.5)$ & $11.8 \pm 1.2^{\mathrm{c}}(8.6-14.1)$ & $11.3 \pm 1.5^{\mathrm{d}}(8.0-13.6)$ \\
19.7 (G) & 25 & $4.7 \pm 0.5^{\mathrm{e}}(3.6-5.7)$ & $3.6 \pm 0.3^{\mathrm{d}}(3.1-4.2)$ & $7.6 \pm 0.8^{\mathrm{e}}(5.5-8.7)$ & $12.4 \pm 0.8^{\mathrm{d}}(10.5-13.5)$ & $11.8 \pm 1.1^{\mathrm{d}}(9.3-13.3)$ \\
21.1 & 25 & $4.4 \pm 0.3^{\mathrm{d}}(3.8-4.9)$ & $2.8 \pm 0.5^{\mathrm{c}}(1.7-3.5)$ & $7.0 \pm 0.9^{\mathrm{e}}(4.9-8.2)$ & $11.2 \pm 0.9^{\mathrm{c}}(8.5-12.3)$ & $6.1 \pm 0.6^{\mathrm{b}}(4.6-7.2)$ \\
22.4 (G6) & 27 & $5.3 \pm 0.8^{\mathrm{e}}(3.9-7.1)$ & $3.7 \pm 0.4^{\mathrm{d}}(2.8-4.4)$ & $7.1 \pm 1.1^{\mathrm{e}}(5.0-9.5)$ & $12.6 \pm 1.6^{\mathrm{d}}(10.0-16.7)$ & $13.7 \pm 1.6^{\mathrm{e}}(10.6-17.0)$ \\
23.5 (G7) & 29 & $5.9 \pm 0.7^{\mathrm{f}}(3.8-7.0)$ & $4.0 \pm 0.6^{\mathrm{d}}(2.6-5.0)$ & $7.9 \pm 1.3^{\mathrm{e}}(4.8-10.4)$ & $14.9 \pm 1.7^{\mathrm{e}}(10.5-18.0)$ & $15.6 \pm 2.2^{\mathrm{f}}(12.4-20.6)$ \\
24.7 (G4) & 25 & $6.4 \pm 1.3^{\mathrm{f}}(3.8-9.3)$ & $5.0 \pm 1.1^{\mathrm{e}}(2.3-6.7)$ & $8.2 \pm 1.7^{\mathrm{e}}(4.9-13.1)$ & $14.4 \pm 2.4^{\mathrm{d}}(9.2-18.8)$ & $17.0 \pm 2.9^{\mathrm{g}}(11.4-22.6)$ \\
& & & & & & \\
\hline
\end{tabular}
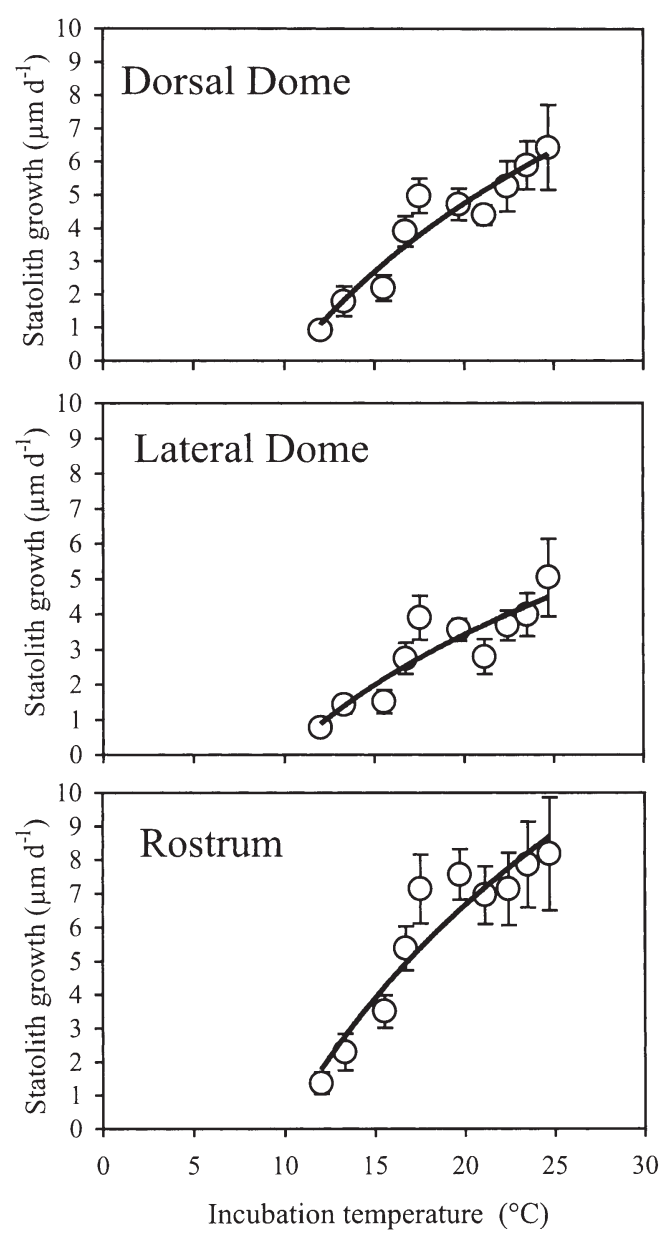

Fig. 3. Loligo vulgaris. Mean $( \pm \mathrm{SD})$ daily statolith growth in 3 areas of statolith of embryos incubated under laboratory conditions at temperatures ranging from 12.0 to $24.7^{\circ} \mathrm{C}$. Growth was recorded between 2 consecutive tetracycline marks. Logarithmic trend is indicated for each plot incubation $\left(12\right.$ and $24.7^{\circ} \mathrm{C}$ : Table 2). The logarithmic function fitted this temperature versus growth relationship well for all measurements obtained (equations in Table 3).

\section{Embryonic statolith of wild squid and temperatures inferred for spawning sites}

The width of the embryonic growth increments of Loligo vulgaris ranged from $0.97 \mu \mathrm{m}$ for squid hatched during April and collected off the NW Iberian Peninsula, to $3.64 \mu \mathrm{m}$ for squid hatched in September and collected from the Central Mediterranean. Table 4 shows the embryonic increment widths for all geographic areas for each month of hatching. No differences in the mean increment width were found between sexes ( $t$-test, $\mathrm{p}>$ 0.6). In general, embryonic increment widths of Mediterranean squid were wider than those of Atlantic squid. To enable comparisons between the mean increment width of the statoliths from the different collections, data from all individuals for each collection were pooled ('All' in Table 4). The 5 collections differed in mean increment width (ANOVA, p < 0.0001). However, no differences were found between the 2 Saharan collections or the 2 Mediterranean collections ( $p>0.3$ ). The NW Iberian Peninsula collection differed from the others $(p<0.05)$, having lower mean increment widths. The mean width for all statoliths from the Saharan Bank was $1.90 \mu \mathrm{m}$ $( \pm 0.33 \mathrm{SD})$, and for all the Mediterranean statoliths was $2.31 \mu \mathrm{m}( \pm 0.39 \mathrm{SD})$. No differences were found $(\mathrm{p}>0.2)$ between increment widths in the cold (winter-spring) versus warm (summer-autumn) months of the year for each collection, except for the Eastern Mediterranean group ( $<<0.05)$. 


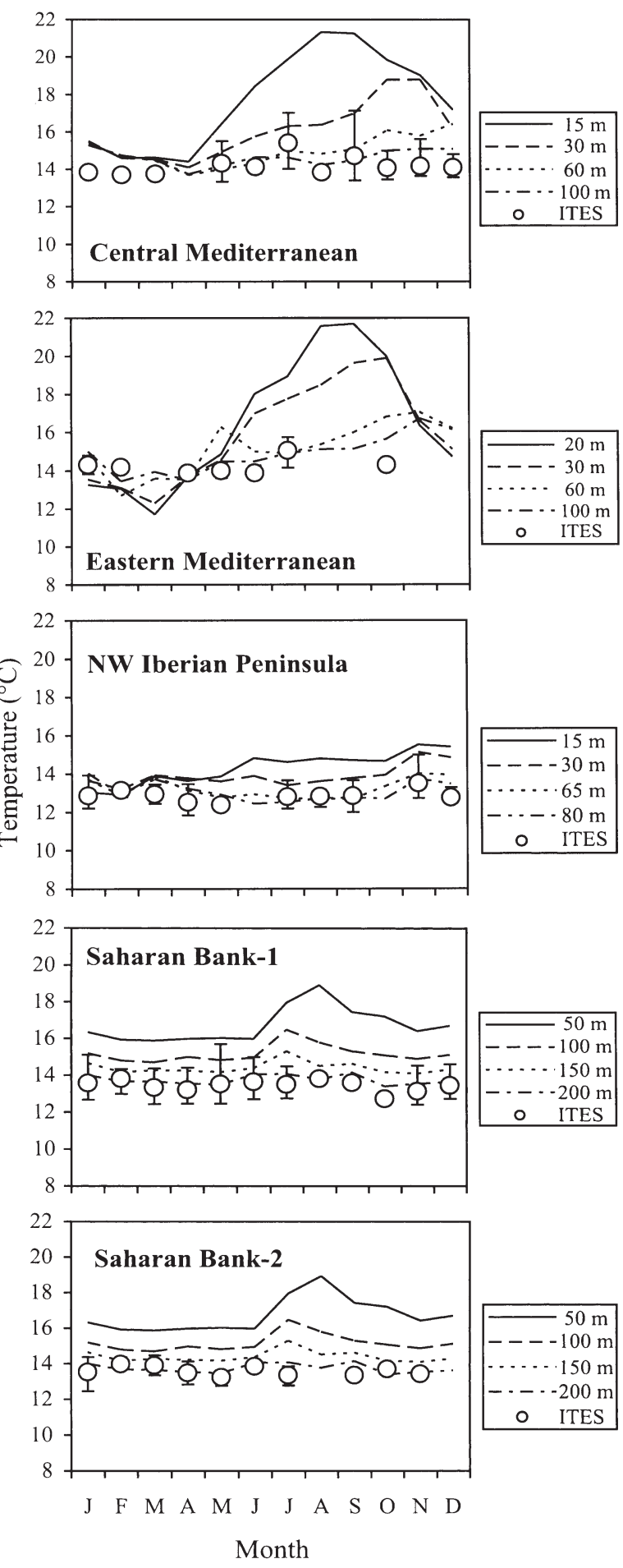

Fig. 4. Loligo vulgaris. Temperatures inferred from embryonic statolith (ITES) on a monthly basis for statolith collections of wild squid from Central and Eastern Mediterranean, NW Iberian Peninsula, and 2 collections from Saharan Bank. Bars indicate minimum and maximum ranges. Mean monthly temperature profiles at sea, for different depths (in $\mathrm{m}$ ), are also indicated for the respective areas. Temperature at sea for Saharan Bank corresponds to that in the area of Cape Blanco $\left(20.5^{\circ} \mathrm{N}, 17.5^{\circ} \mathrm{W}\right)$
The temperatures inferred from the increment width, using the statolith growth equation obtained in the laboratory (Eq. 3 in Table 3) represent the estimated incubation temperatures at sea, ranging from $11.8^{\circ} \mathrm{C}$ for the NW Iberian Peninsula squid hatched during April to $17.1^{\circ} \mathrm{C}$ for the Central Mediterranean squid hatched in September (Table 5). The mean inferred temperature for all statoliths from the Saharan Bank was $13.5^{\circ} \mathrm{C}( \pm 0.6 \mathrm{SD})$, and for all Mediterranean statoliths it was $14.3^{\circ} \mathrm{C}( \pm 0.8 \mathrm{SD})$. Comparisons between the estimated and the observed seawater temperatures in different months and depths for all geographical areas investigated were also made (Fig. 4).

\section{DISCUSSION}

\section{Embryonic statoliths and spawning areas}

The present results indicate that embryonic statolith growth under laboratory conditions is dependent on the incubation temperature, which directly affects both metabolic rates and growth in squids (O'Dor \& Wells 1987). The temperature inferred from the embryonic increment widths of statoliths indicates that embryonic development of Loligo vulgaris in the geographic regions sampled occurs at temperatures from 12 to $17^{\circ} \mathrm{C}$. Therefore, at sea, these squid select a temperature range to spawn, avoiding high temperatures. As spawning takes place throughout the year, the depth selected to spawn changes as a function of the ambient temperature. Villa et al. (1997) corroborated our laboratory results with field data. Based on monthly egg sampling and associated hydrographic parameters throughout the year on the south coast of Portugal, egg masses of $L$. vulgaris were recorded between temperatures of 13 and $19^{\circ} \mathrm{C}$. The Portuguese eggs were collected at depths between 2 and $35 \mathrm{~m}$ (mostly between 20 and $30 \mathrm{~m}$ ) by SCUBA diving (Villa et al. 1997). These field results indicated that the temperatures inferred from embryonic statolith analysis follow the temperature ranges recorded at sea. As mentioned earlier, Mediterranean squid have wider embryonic increments than Atlantic squid, indicating slightly higher sea temperatures during the development of the egg masses for the former. This difference may be related to the fact that the shelf waters of Mediterraean Sea are warmer than the coastal Atlantic regions sampled during the present study (Brasseur et al. 1996, Conkright et al. 1998).

For the Saharan Bank area, the inferred incubation temperatures indicate the possible existence of spawning areas of Loligo vulgaris at or below $200 \mathrm{~m}$ depth (a depth that may be close to the limit for the species). Our results inferred from statoliths may thus be under- 
Table 3. Loligo vulgaris. Growth equations for embryonic statoliths of squid incubated under laboratory conditions at temperatures from 12.0 to $24.7^{\circ} \mathrm{C}$. Length measured between 2 consecutive tetracycline marks. Growth equations were logarithmic: $y=b \ln (x)-a$. SG: statolith growth $\left(\mu \mathrm{m}\right.$ or $\left.\% \mathrm{~d}^{-1}\right) ; \mathrm{T}$ : temperature $\left({ }^{\circ} \mathrm{C}\right) ; \mathrm{SE}$ : standard error of $b_{;} \mathrm{n}$ : number of hatchling squid for which statoliths were measured

\begin{tabular}{|c|c|c|c|c|}
\hline Equation no. & Equation & $\mathrm{r}^{2}$ & SE & $\mathrm{n}$ \\
\hline $\begin{array}{l}\text { Statolith total length } \\
\text { (1) Growth }\left(\mu \mathrm{m} \mathrm{d}^{-1}\right) \\
\text { (2) Growth }\left(\% \mathrm{~d}^{-1}\right)\end{array}$ & $\begin{array}{l}\mathrm{SG}=17.450 \ln (T)-40.768 \\
\mathrm{SG}=17.650 \ln (T)-41.302\end{array}$ & $\begin{array}{l}0.891 \\
0.654\end{array}$ & $\begin{array}{l}0.031 \\
0.050\end{array}$ & $\begin{array}{l}263 \\
263\end{array}$ \\
\hline $\begin{array}{l}\text { Statolith zones } \\
\text { (3) Dorsal dome }\left(\mu \mathrm{m} \mathrm{d}^{-1}\right) \\
\text { (4) Lateral dome }\left(\mu \mathrm{m} \mathrm{d}^{-1}\right) \\
\text { (5) Rostrum }\left(\mu \mathrm{m} \mathrm{d} \mathrm{d}^{-1}\right)\end{array}$ & $\begin{array}{l}\mathrm{SG}=7.1673 \ln (T)-16.730 \\
\mathrm{SG}=4.9834 \ln (T)-11.507 \\
\mathrm{SG}=9.5911 \ln (T)-22.067\end{array}$ & $\begin{array}{l}0.908 \\
0.812 \\
0.891\end{array}$ & $\begin{array}{l}0.013 \\
0.012 \\
0.020\end{array}$ & $\begin{array}{l}263 \\
263 \\
263\end{array}$ \\
\hline
\end{tabular}

ence embryonic statolith growth according to different bottom environments, as light intensity decreases exponentially with depth (Jerlov 1968). Light and photoperiod effects on embryonic squid statoliths are practically unknown, and should be studied in the future. For example, in embryos of Atlantic salmon Salmo salar, the effect of photoperiod has been known to influence the rate of increment deposition of their otoliths (Geffen 1983). However, Jackson et al. (1993) found a ratio of 1 increment $\mathrm{d}^{-1}$ in Sepioteuthis lessoniana squid reared under constant $24 \mathrm{~h} \mathrm{~d}^{-1}$ lighting

estimates. Despite the heavy fishing effort in the area (Balguerías et al. 2000), no spawning areas or egg masses of L. vulgaris have been collected or reported for the Saharan Bank. It is therefore difficult to check the theoretical results obtained in the present study. The hatching peak of $L$. vulgaris from the Saharan Bank has been suggested to occur in the month of May (Raya et al. 1999), indicating that embryonic development occurs mainly in April. On the Saharan Bank $\left(25^{\circ} 37^{\prime} \mathrm{N}, 14^{\circ} 51^{\prime} \mathrm{W}\right)$ during April over a bottom depth of $50 \mathrm{~m}$, the water temperature (at $40 \mathrm{~m}$ depth) was $13.3^{\circ} \mathrm{C}$; over a bottom depth of $70 \mathrm{~m}$, the temperature (at $50 \mathrm{~m}$ depth) was $13.6^{\circ} \mathrm{C}$ (Manríquez et al. 1976). These temperatures match our results for the temperatures inferred from embryonic statoliths incubated in April and for both statolith collections examined from that area (Table 5, Fig. 4). Further research is needed to confirm these possible spawning areas. In this connection, the existence of deep spawning at depths of 115 to $125 \mathrm{~m}$ has been recorded for $L$. v. reynaudii, indicating that spawning occurs in 2 contrasting bottom environments, the warm inshore and cold mid-shelf off the south coast of South Africa (Roberts \& Sauer 1994, Roberts et al. 2002). Guerra \& Rocha (1994) indicate that the spawning season for $L$. vulgaris off the NW Iberian Peninsula can continue throughout the year, but mainly falls between December and April, with a peak in February. These authors reported 3 egg masses collected in January at depths of 30 to $65 \mathrm{~m}$, and an egg mass collected in June at $15 \mathrm{~m}$. The temperature inferred from NW Iberian Peninsula statoliths indicates that peak spawning can take place in relatively shallow water during the period of watermixing. Some squid may spawn deeper than $30 \mathrm{~m}$ during the following warmer months (Fig. 4). We have no data with which to compare the egg mass reported for June.

It is known that light influences the hatching period in Loligo vulgaris (Paulij et al. 1990). Light may influ- throughout their entire life span, indicating a possible major endogenous component in the rate of posthatching statolith growth. It should be taken into account that during the present study all incubations in the laboratory were done under constant, low-intensity illumination. Additional sources of variation are also suspected, as irregularities were found during the present study at the extreme egg incubation temperatures of 12 and $24.7^{\circ} \mathrm{C}$. These temperatures seem to be unusual for L. vulgaris egg incubation at sea, producing irregular statolith growth or low embryo survival in the laboratory. The low incubation temperature of $12^{\circ} \mathrm{C}$ produced a less-than-daily increment deposition rate in embryonic statoliths of L. vulgaris (Villanueva $2000 b)$. This effect could be a source of error when inferring low temperatures, as we assumed a daily deposition rate when counting and measuring all statolith increment widths from wild squid. Loliginid embryos are very sensitive to temperature, and for $L$. V. reynaudii, the occurrence of morphological abnormalities in embryos increases to $50 \%$ at laboratory incubation temperatures of 9 and $21^{\circ} \mathrm{C}$ (Oosthuizen et al. 2002).

\section{Embryonic life and paralarval variability}

Temperature is the main factor that regulates the duration of embryonic development in cephalopods (von Boletzky 1987). For Loligo vulgaris, differences in this duration can be up to $50 \mathrm{~d}$ (the incubation period in the laboratory ranges from $70 \mathrm{~d}$ at $10^{\circ} \mathrm{C}$ to $25 \mathrm{~d}$ at $20^{\circ} \mathrm{C}$; von Boletzky 1974). The temperatures inferred at sea from embryonic statolith growth during the present study ranged from $11.8^{\circ} \mathrm{C}$ for squid hatched during April and collected off the NW Iberian Peninsula, to $17.1^{\circ} \mathrm{C}$ for the squid hatched in September and collected from the Central Mediterranean. Using the relationship between temperature and duration of embryonic development in L. vulgaris provided by von 


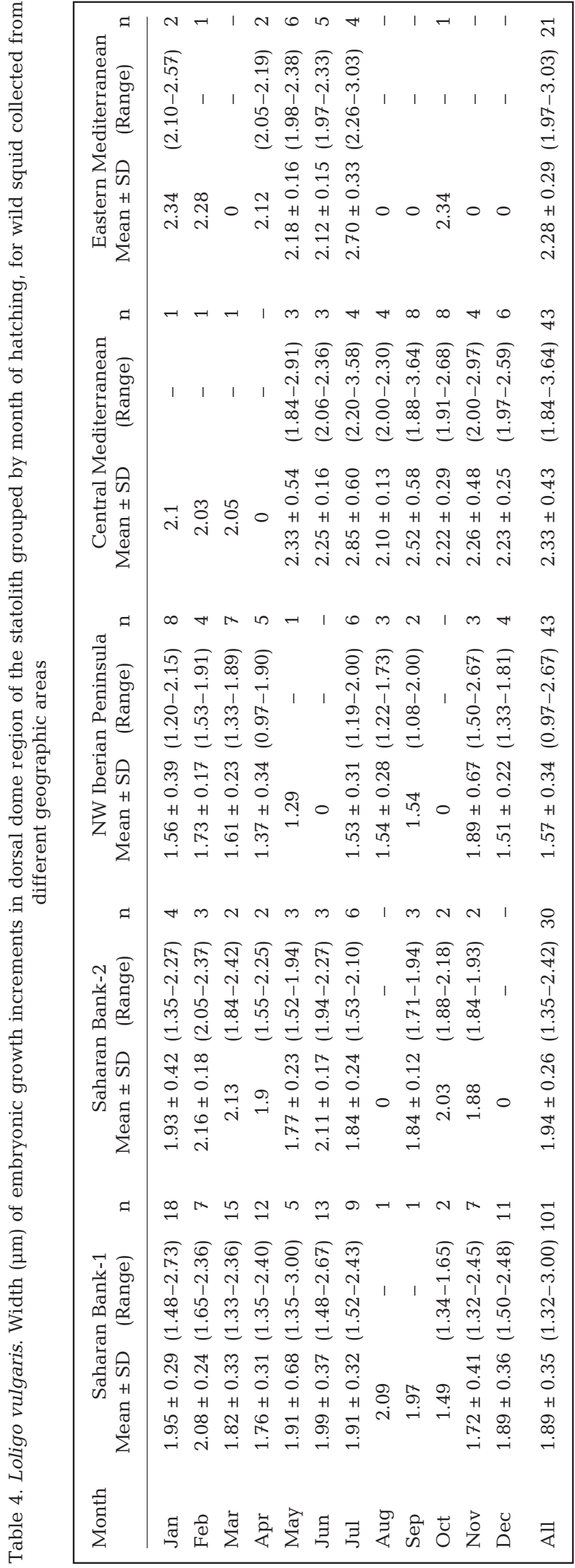

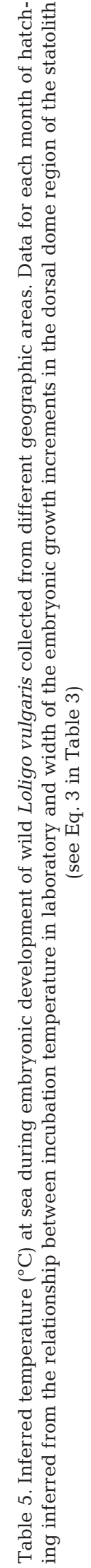

\begin{tabular}{|c|c|c|c|c|c|}
\hline 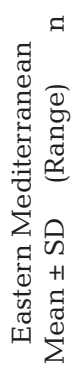 & 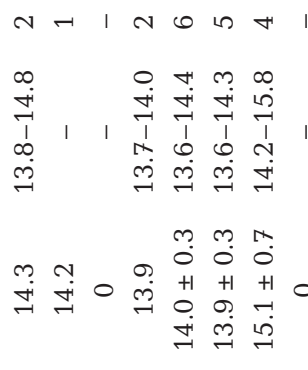 & $\begin{array}{ll} & 1 \\
& 1 \\
1 & 1 \\
& 1 \\
0 & 0\end{array}$ & $\begin{array}{l}-1 \\
1 \\
\stackrel{\mathscr{m}}{+}\end{array}$ & ' & 0 \\
\hline 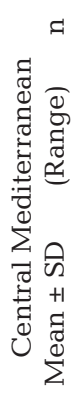 & 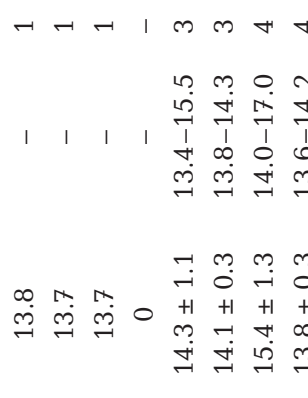 & & $\begin{array}{l}0 \\
\ddot{0} \\
+1\end{array}$ & & 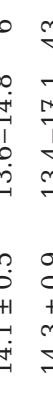 \\
\hline 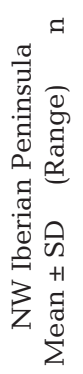 & 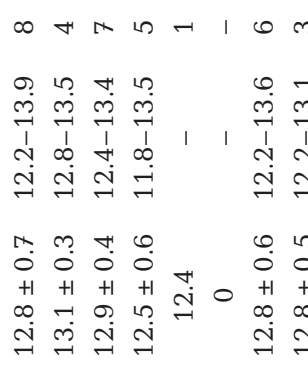 & 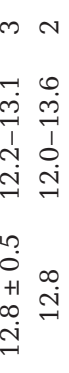 & 1 & 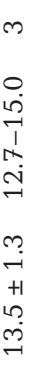 & 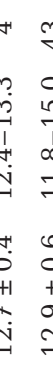 \\
\hline 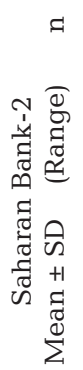 & 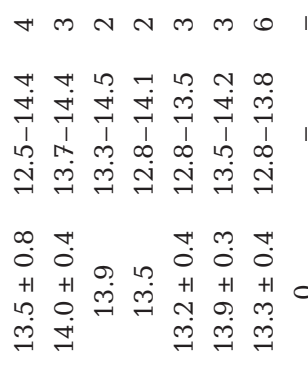 & 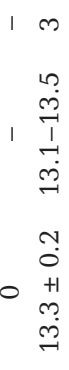 & $\begin{array}{l}N \\
0 \\
\stackrel{1}{*} \\
\stackrel{1}{r}\end{array}$ & N & 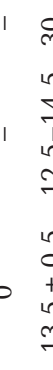 \\
\hline 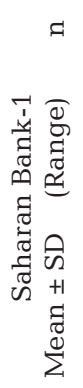 & 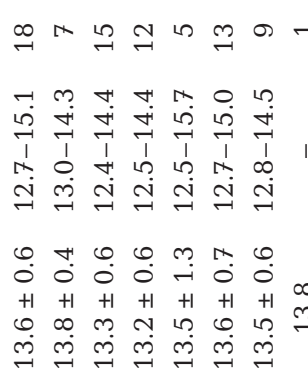 & 1 & 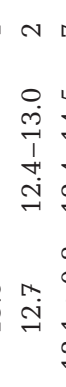 & & $\Rightarrow$ \\
\hline $\begin{array}{l}\text { 志 } \\
\sum_{\Sigma}^{0}\end{array}$ & 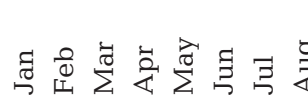 & & & & \\
\hline
\end{tabular}


Boletzky (1987), it can be estimated that the duration of the embryonic development for both extreme temperatures inferred from statoliths ranged from 55 to $30 \mathrm{~d}$, respectively. Likewise, the mean inferred temperature for all statoliths from the NW Iberian Peninsula $\left(12.9^{\circ} \mathrm{C}\right)$ and the Mediterranean $\left(14.3^{\circ} \mathrm{C}\right)$ gave estimates of mean duration of embryonic periods of 47 and $40 \mathrm{~d}$, respectively. These estimates indicate that the NW Iberian Peninsula egg masses remained at sea 1 wk longer (18\%) than the Mediterranean egg masses (nearly 1 mo longer [83\%] when comparing minimum and maximum ranges).

The differing durations of the incubation periods of Loligo vulgaris in different geographic areas is a source of paralarval variation and differentiated recruitment. Loliginid squids do not care for their eggs after spawning, and egg masses attached to a substratum and remaining for a long period at sea are exposed to 2 major risks. First is the probability of encountering strong periods of turbulence. Moving sand after periods of strong wind has been observed to cover egg masses of $L$. V. reynaudii. Large egg beds of the same species can be detached and presumably displaced by strong turbulence (Sauer et al. 1993). A second risk is predation. Polychaetes of the families Capitellidae, Syllidae, Lumbrinereidae and Sabellidae have been observed on the egg masses of $L$. vulgaris. They do not prey on the embryos, but eat the gelatinous mass, swelling the structure and making perforations which are used by Nematoda, Harpacticoidea and Ciliata (von Boletzky \& Dohle 1967). Predation by sea stars Patiria sp. and sea urchins Lytechinus sp. on egg masses of Loligo opalescens (Hixon 1983) and predation by scyliorhinid sharks Poroderma pantherinum and sparid fish Spondyliosoma emarginatum on egg masses of L. v. reynaudii (Sauer \& Smale 1991, 1993) has been reported. In addition, the impact of fishing damage to egg beds has been described for $L$. v. reynaudii (Sauer 1995), and egg masses of $L$. forbesi are incidentally caught in demersal trawls (Lordan \& Casey 1999, Salman \& Laptikhovsky 2002).

Conversely, slow development at a lower temperature can improve yolk conversion in cephalopods producing larger hatchlings, as occurs in the cuttlefish Sepia officinalis (Bouchaud 1991) and larval fishes (Blaxter 1992). Embryonic incubation in the laboratory at cool temperatures (mean $12.2^{\circ} \mathrm{C}$ ) produced Loligo vulgaris hatchlings that were significantly heavier ( $8 \%)$ and longer $(7 \%)$ than embryos incubated at warmer temperatures (mean $19.5^{\circ} \mathrm{C}$ ) (Villanueva 2000a). Larger L. vulgaris hatchlings probably have an initial competitive advantage due to their greater swimming power, which may enhance food-searching and prey-capture capacities (Packard 1969, Chen et al. 1996, Villanueva et al. 1996), making them less vulnerable to small predators. Thus, a compromise between the risks of long versus short embryonic incubation duration, and the resulting hatchling size and hatchling competence, probably exists. From the results of the present study on inferred differential incubation temperatures, Atlantic $L$. vulgaris hatchlings would be expected to be larger in size than those from the Mediterranean. Future studies are necessary to test this hypothesis and to investigate the respective advantages for each paralarval population by determining what other developmental factors may be involved. As an example, in hatchlings of the lolignid squid Sepioteuthis lessoniana originating from maternally identical egg strings, incubated under constant temperature in laboratory, body size and statolith size are larger in hatchlings hatching later, with embryonic duration ranging from 22 to $27 \mathrm{~d}$ (Ikeda et al. 1999). During the present study, for each region and month, egg masses of $L$. vulgaris developed in a relatively small range of water temperature. However, in some extreme cases, differences in the inferred temperature for the same month can be up to $3.2^{\circ} \mathrm{C}$ (e.g. May, Saharan Bank-1) and $3.7^{\circ} \mathrm{C}$ (e.g. September, Central Mediterranean: Table 5, Fig. 4). In such extreme cases, paralarval squid with a different embryonic developmental history and a different degree of competence at hatching can co-exist in the same squid recruitment area. The dynamics and degree of co-existence of loliginid hatchlings with different embryonic developmental histories is an unexplored field that needs further research.

Acknowledgements. Dr. C. Nigmatullin (AtlantNIRO, Kaliningrad, Russia) and Dr. S. Ragonese (Istituto di Ricerche sulle Risorse Marine e l'Ambiente, Consiglio Nazionale delle Ricerche, Mazara del Vallo, Italy) kindly provided the 'Saharan Bank-1' and the 'Central Mediterranean' collections of statoliths for re-examination, respectively. Dr. J. David (Marine and Coastal Management, Cape Town) corrected the English of the manuscript. This study was partially funded by the research project MAR95-1919-C05-04 of the Comisión Interministerial de Ciencia y Tecnología of Spain to R.V. and by the EU project CEPHSTOCK.

\section{LITERATURE CITED}

Arkhipkin A (1995) Age, growth and maturation of the European squid Loligo vulgaris (Myopsida, Loliginidae) on the West Saharan shelf. J Mar Biol Assoc UK 75:593-604

Balguerías E, Quintero ME, Hernández-González, CL (2000) The origin of the Saharan Bank cephalopod fishery. ICES J Mar Sci 57:15-23

Bettencourt V, Coelho L, Andrade JP, Guerra A (1996) Age and growth of the squid Loligo vulgaris off the south coast of Portugal, using statolith analysis. J Molluscan Stud 62: 359-366

Blaxter JHS (1992) The effect of temperature on larval fishes. Neth J Zool 42:336-357

Bouchaud O (1991) Energy consumption of the cuttlefish 
Sepia officinalis L. (Mollusca: Cephalopoda) during embryonic development, preliminary results. Bull Mar Sci 49: 333-340

Brasseur P, Brankart JM, Schoenauen R, Beckers JM (1996) Seasonal temperature and salinity fields in the Mediterranean Sea: climatological analyses of an historical data set. Deep-Sea Res 43:159-192

Chen DS, Dykhuizen GV, Hodge J, Gilly WF (1996) Ontogeny of copepod predation in juvenile squid (Loligo opalescens). Biol Bull (Woods Hole) 190:69-81

Clarke MR (1978) The cephalopod statolith — an introduction to its form. J Mar Biol Assoc UK 58:701-712

Coelho ML, Quintela J, Bettencourt V, Olavo G, Villa H (1994) Population structure, maturation patterns and fecundity of the squid Loligo vulgaris from southern Portugal. Fish Res 21:87-102

Collins MA, Burnell GM, Rodhouse PG (1995) Age and growth of the squid Loligo forbesi (Cephalopoda: Loliginidae) in Irish waters. J Mar Biol Assoc UK 75:605-620

Conkright $\mathrm{M}$, Levitus S, O'Brien $\mathrm{T}$, Boyer $\mathrm{T}$, Antonov $\mathrm{J}$, Stephens C (1998) World ocean atlas 1998: CD-ROM data set documentation. Tech. Rep. 15, National Oceanographic Data Center Internal Report, Silver Spring, MD

Durholtz MD, Lipinski MR (2000) Influence of temperature on the microstructure of statoliths of the thumbstall squid Lolliguncula brevis. Mar Biol 136:1029-1037

Durholtz MD, Lipinski MR, Field JG (2002) Laboratory validation of periodicity of incrementation in statoliths of the South African chokka squid Loligo vulgaris reynaudii (d'Orbigny, 1845): a reevaluation. J Exp Mar Biol Ecol 279: 41-59

Geffen AJ (1983) The deposition of otolith rings in Atlantic salmon, Salmo salar L., embryos. J Fish Biol 23:467-474

Gowland FC, Moltschaniwskyj NA, Steer MA (2002) Description and quantification of developmental abnormalities in a natural Sepioteuthis australis spawning population (Mollusca: Cephalopoda). Mar Ecol Prog Ser 243:133-141

Guerra A, Rocha F (1994) The life history of Loligo vulgaris and Loligo forbesi (Cephalopoda: Loliginidae) in Galician waters (NW Spain). Fish Res 21:43-69

Hixon RF (1983) Loligo opalescens. In: Boyle PR (ed) Cephalopod life cycles, Vol 1. Academic Press, London, p 95-114

Ikeda Y, Wada Y, Nobuaki A, Sakamoto W (1999) Note on size variation of body and statoliths in the oval squid Sepioteuthis lessoniana hatchlings. J Mar Biol Assoc UK 79: $757-759$

Jackson GD (1990) Age and growth of the tropical nearshore loliginid squid Sepioteuthis lessoniana determined from statolith growth-ring analysis. Fish Bull US Fish Wildl Serv 88:113-118

Jackson GD (1994) Application and future potential of statolith increment analysis in squids and sepioids. Can J Fish Aquat Sci 51:2612-2625

Jackson GD, Moltschaniwskyj NA (2001) The influence of ration level on growth and statolith increment width of the tropical squid Sepioteuthis lessoniana (Cephalopoda: Loliginidae): an experimental approach. Mar Biol 138:819-825

Jackson GD, O'Dor R (2001) Time, space and the ecophysiology of squid growth, life in the fast lane. Vie Milieu 51: 205-215

Jackson GD, Arkhipkin AI, Bizikov VA, Hanlon RT (1993) Laboratory and field corroboration of age and growth from statoliths and gladii of the loliginid squid Sepioteuthis lessoniana (Mollusca: Cephalopoda). In: Okutani T, O'Dor RK, Kubodera T (eds) Recent advances in cephalopod fisheries biology. Tokai University Press, Tokyo, p 189-200 Jerlov NG (1968) Optical oceanography. Elsevier, Copenhagen
Lipinski MR (1986) Methods for the validation of squid age from statoliths. J Mar Biol Assoc UK 66:505-526

Lipinski MR, Dawe E, Natsukari Y (1991) Introduction. In: Jereb P, Ragonese S, Boletzky S (eds) Squid age determination using statoliths. Proc Int Workshop, 9-14 October 1989. NTR-ITPP Spec Publ No. 1. Istituto di Technologia della Pesca e del Pescato (ITPP), Mazzara del Vallo, p $97-112$

Lipinski MR, Durholtz MD, Underhill LG (1998) Field validation of age readings from the statoliths of chokka squid (Loligo vulgaris reynaudii d'Orbigny, 1845) and an assessment of associated errors. ICES J Mar Sci 55:240-257

Lordan C, Casey J (1999) The first evidence of offshore spawning in the squid species Loligo forbesi. J Mar Biol Assoc UK 79:379-381

Mangold-Wirz K (1963) Biologie des céphalopodes benthiques et nectoniques de la Mer Catalane. Vie Milieu 13: $1-285$

Manríquez M, Rubiés P, Cruzado A (1976) Datos hidrográficos de la región de afloramiento del NW de África: campaña 'Atlor V' entre cabo Bojador y cabo Blanco. Result Exped Cient Buque Oceangr 'Cornide de Saavedra' 5: 123-160

Martins MC (1997) The statoliths of Loligo vulgaris and L. forbesi hatchlings: preliminary morphological study. Vie Milieu 47:171-176

MEDATLAS (2002) Mediterranean and Black Sea database of temperature, salinity and bio-chemical parameters-climatological atlas. CD-ROM. Systèmes d'informations Scientifiques pour la Mer (SISMER), IFREMER, Plouzané

Morris CC (1991) Methods for in situ experiments on statolith increment formation, with results for embryos of Alloteuthis subulata. In: Jereb P, Ragonese S, Boletzky S (eds) Squid age determination using statoliths. Proc Int Workshop, 9-14 October 1989. NTR-ITPP Spec Publ No. 1. Istituto di Technologia della Pesca e del Pescato (ITPP), Mazzara del Vallo, p 67-72

Morris CC (1993) Environmental effects on increment formation in embryonic statoliths of the squid Alloteuthis subulata (Myopsida: Loliginidae). J Cephalopod Biol 2:23-32

Natsukari Y, Komine N (1992) Age and growth estimation of the European squid, Loligo vulgaris, based on statolith microstructure. J Mar Biol Assoc UK 72:271-280

Natsukari Y, Nakasone T, Kazunari O (1988) Age and growth of loliginid squid Photololigo edulis (Hoyle, 1885). J Exp Mar Biol Ecol 116:177-190

O'Dor RK, Wells MJ (1987) Energy and nutrient flow. In: Boyle PR (ed) Cephalopod life cycles, Vol 2. Academic Press, London, p 109-133

Oosthuizen A, Roberts MJ, Sauer WHH (2002) Early postcleavage stages and abnormalities identified in the embryonic development of chokka squid eggs Loligo vulgaris reynaudii. S Afr J Mar Sci 24:379-382

Packard A (1969) Jet propulsion and the giant fibre response of Loligo. Nature 221:875-877

Paulij WP, Herman PMJ, Van Hannen E, Denucé JM (1990) The impact of photoperiodicity on hatching of Loligo vulgaris and Loligo forbesi. J Mar Biol Assoc UK 70:597-610

Raya CP, Balguerias E, Fernández-Núñez MM, Pierce GJ (1999) On reproduction and age of the squid Loligo vulgaris from the Saharan Bank (north-west African coast). J Mar Biol Assoc UK 79:111-120

Roberts MJ, Sauer WHH (1994) Environment: the key to understanding the South African chokka squid (Loligo vulgaris reynaudii) life cycle and fishery? Antarct Sci 6:249-258

Roberts MJ, Barange M, Lipinski MR, Prowse MR (2002) Direct hydroacustic observations of chokka squid Loligo 
vulgaris reynaudii spawning activity in deep water. S Afr J Mar Sci 24:387-393

Rocha F, Guerra A (1999) Age and growth of two sympatric squid Loligo vulgaris and Loligo forbesi, in Galician waters (north-west Spain). J Mar Biol Assoc UK 79:697-707

Salman A, Laptikhovsky V (2002) First occurrence of egg masses of Loligo forbesi (Cephalopoda: Loliginidae) in deep waters of the Aegean Sea. J Mar Biol Assoc UK 82: 925-926

Sauer WHH (1995) The impact of fishing on chokka squid Loligo vulgaris reynaudii concentrations on inshore spawning grounds in the south-eastern Cape, South Africa. S Afr J Mar Sci 16:185-193

Sauer WHH, Smale MJ (1991) Predation patterns on the inshore spawning grounds of the squid Loligo vulgaris reynaudii (Cephalopoda: Loliginidae) off the southeastern Cape, South Africa. S Afr J Mar Sci 11:513-523

Sauer WHH, Smale MJ (1993) Spawning behaviour of Loligo vulgaris reynaudii in shallow coastal waters of the southeastern Cape, South Africa. In: Okutani T, O'Dor RK, Kubodera T (eds) Recent advances in cephalopod fisheries biology. Tokai University Press, Tokyo, p 489-498

Sauer WHH, McCarthy C, Smale MJ, Koorts AS (1993) An investigation of the egg distribution of the chokka squid, Loligo vulgaris reynaudii, in Krom Bay, South Africa. Bull Mar Sci 53:1066-1077

Steer MA, Moltschaniwskyj NA, Gowland FC (2002) Tempo-

Editorial responsibility: Otto Kinne (Editor),

Oldendorf/Luhe, Germany ral variability in embryonic development and mortality in the southern calamary Sepioteuthis australis: a field assessment. Mar Ecol Prog Ser 243:143-150

Villa H, Quintela J, Coelho ML, Icely JD, Andrade JP (1997) Phytoplankton biomass and zooplankton abundance on the south coast of Portugal (Sagres), with special reference to spawning of Loligo vulgaris. Sci Mar 61:123-129

Villanueva R (2000a) Effect of temperature on statolith growth of the European squid Loligo vulgaris during early life. Mar Biol 136:449-460

Villanueva R (2000b) Differential increment-deposition rate in embryonic statoliths of the loliginid squid Loligo vulgaris. Mar Biol 137:161-168

Villanueva R, Nozais C, Boletzky S (1996) Swimming behaviour and food searching in planktonic Octopus vulgaris from hatching to settlement. J Exp Mar Biol Ecol 208: 169-184

von Boletzky S (1974) Élevage de céphalopodes en aquarium. Vie Milieu 24:309-340

von Boletzky S (1987) Embryonic phase. In: Boyle PR (ed) Cephalopod life cycles, Vol 2. Academic Press, London, p 5-31

von Boletzky S (1998) Cephalopod eggs and egg masses. Oceanogr Mar Biol Annu Rev 36:341-371

von Boletzky S, Dohle W (1967) Observations sur un capitellidé (Capitella hermaphrodita sp. n.) et d'autres polychètes habitant la ponte de Loligo vulgaris. Vie Milieu 18:79-98

Submitted: September 2, 2002; Accepted: January 7, 2003 Proofs received from author(s): April 15, 2003 